\title{
Risk Management Education: An Examination of Crop Producers' Participation in Recent Programs and of Their Desire for Additional Training
}

\author{
Thomas O. Knight, Keith H. Coble, George F. Patrick, and \\ Alan E. Baquet
}

\begin{abstract}
Risk manugement education has been a focus of U.S. fanm policy since 1996. In support of significant ongoing United States Department of Agriculture (USDA) educational efforts, this study examines agricultural producers' educational needs and interests. Data obtained through a survey of crop producers are used in probit models examining interest in additional training in five areas including forward contracting, futures and options, crop yield insurance, crop revenue insurance, and financial management. The study results should be useful in determining appropriate risk management education program content and in identifying and tailoring to specific target audiences.
\end{abstract}

Key Words: commodity futures, commodity options, crop insurance, forward contracting, risk management

JEL Classifications: D81, D83, Q16

Risk issues have dominated U.S. farm policy deliberations since the 1996 FAIR Act was signed into law. Enactment of this legislation and contemporaneous trade liberalization measures stimulated a vigorous debate regarding the capacity of farmers to cope with the loss of income-stabilizing deficiency payments (Collins and Glauber). This debate intensified in 1998, when regional yield losses and com-

Thomas O. Knight is professor, Department of Agricultural and Applied Economics, Texas Tech University, Lubbock, TX. Keith H. Coble is associate professor; Department of Agricultural Economics, Mississippi State University, Mississippi State, MS. George F Patrick is professor, Department of Agricultural Economics, Purdue University, West Lafayette, IN. Alan E. Baquet is associate vice chancellor, Institute of Agriculture and Natural Resources, University of Nebraska, Lincoln, NE. modity price declines led to a substantial drop in net cash farm income from market sources. Disaster legislation, passed in that year, marked the first departure since 1994 from a policy objective of avoiding reliance on ad hoc disaster assistance. Similar legislation in 1999 and 2000 raised direct government payments to farmers to record levels of more than $\$ 20$ billion in each year. This repeated resort to ad hoc disaster programs led the 106th Congress to focus on strengthening the farm income safety net, with lengthy deliberations culminating in enactment of the Agricultural Risk Protection Act of 2000. Additional risk protection was incorporated into the Food Security and Rural Investment Act of 2002 in the form of counter-cyclical payments designed to mitigate the effects of troughs in commodity price cycles. These payments were added to 
the preexisting fixed payments and the marketing loan programs. In total, an additional $\$ 37.6$ billion over 6 years was added to commodity program spending.

Throughout the period since 1996, public policies directed toward strengthening the farm income safety net have emphasized the importance of risk management education. Provisions of the FAIR Act directed the USDA to provide appropriate risk management educational programs for U.S. farmers. Further, the act amended the National Agricultural Research, Extension, and Teaching Policy Act of 1977 to include improvement of risk management in the agricultural industry as one of eight specific purposes of agricultural research, extension, and education. Thus the FAIR Act clearly established risk management education as a policy priority. In response to this mandate, the Secretary of Agriculture designated $\$ 5$ million in fiscal year 1998 funding to support a risk management educational initiative.

Continued federal government commitment to risk management education was evident in the Agricultural Risk Protection Act of 2000. This legislation provided $\$ 5$ million annually for fiscal years 2001-2005 to enhance educational programs of the Risk Management Agency (RMA). An additional $\$ 5$ million per year was provided for risk management educational programs to be supported through competitive grants programs administered by the Cooperative State Research, Education, and Extension Service (CSREES). Other sections of the Act were less explicit in their educational objectives, but may direct additional financial support to risk management education.'

Given a continuing policy emphasis on risk management education, it is essential to un-

' In addition to risk management education, ARPA focuses heavily upon strengthening the federal crop insurance program. Provisions of the act are expected to increase crop insurance program expenditures by $\$ 8.2$ billion over a 5-year period. Much of this increased support is in the form of higher crop insurance premium subsidies. Another major area of concentration is expansion of the program to cover more crops and regions, with a significant emphasis on specialty crops. derstand agricultural producers' educational needs and interests. The purpose of this paper is to examine these issues, making use of data obtained through a four-state survey of crop producers conducted in support of the USDA's 1998 risk management education initiative. Specifically, we summarize survey results relating to past risk management educational program participation, the role of extension personnel in those programs, and producers' ratings of alternative learning methods. Then we present results of probit models examining producers ${ }^{*}$ interest in additional training in five areas of risk management including forward contracting, futures and options, crop yield insurance, crop revenue insurance, and financial management. The survey results and analysis we report are unusual in that they provide in-depth analysis of educational needs, desired program emphasis, and target audience composition at an early stage of a major educational initiative directing $\$ 50$ million toward risk management education over a 5-year period.

The remainder of this paper is organized as follows. Historical developments in risk management education and prior studies examining risk management educational issues are reviewed. A conceptual framework for the analysis is developed based on models of human capital investment. Survey procedures are described and results are presented examining past educational program participation, the instructional role of extension personnel in those programs, and producers' ratings of alternative learning methods. This is followed by probit model results examining factors influencing producers' desire for additional risk management training. In the final section, we summarize the study results and comment on their implications.

\section{Hiștorical Perspective and Prior Studies}

\section{Historical Perspective}

The genesis of risk management education in agricultural economics is indistinct because risk considerations were incorporated into some educational programs before risk was 
viewed as a separate subject matter area. Johnson traced the origins of risk management education to the period when theorists, such as Knight, began to grapple with the economic implications of risk for firm decision making, stating,

Beginning in the [nineteen] thirties, the changes, imperfections in knowledge, and foresight which bothered such theorists as Knight began to bother farm management men employing "normal" and "average" data in farm planning, budgeting, and credit work. Thus it was natural that these workers would attempt to use the new managerial concepts being developed by general theorists. . . (p. 4l)

Heady, however, argued that by the mid-1.950s the treatment of risk in educational programs remained inadequate, stating the effectiveness of educational efforts for farmers was diminished due to several apparent assumptions including "[that] all expectations are held with subjective certainty ... [ [and that the] firm has the single goal of profit maximization" (pp. $59-60$ ).

A clear area of progress in risk management education in the 1960 s and 1970 s was in educational programs on commodity marketing. At least by the early 1960 s, university extension faculty were conducting marketing and outlook programs to assist crop producers in evaluating alternative postharvest marketing strategies, with management of seasonal price risk as a primary goal (Grimes). Introduction of live cattle and hog futures contracts in the mid-1960s gave impetus to an intensification of marketing educational programs focusing on use of futures hedging as a pricing and risk management technique. ${ }^{2}$ However, explicit consideration of risk management in more broadly focused educational programs proceeded at a slower pace. For example, as late as 1980 Walker and Nelson concluded that

2 Grimes observes that although exchange-tracled grain futures contracts predaled livestock contracts by several decades, commodity programs diminished the importance of those contracts as risk management tools for crop producers. Thus the introduction of livestock futures contracts stimulated greater interest in educational programs on futures hedging. there was "[little evidence] of significant efforts in either classroom teaching or extension to apply the concepts of decision making under uncertainty in farm management" (p. 29).

An early effort to develop a comprehensive risk management educational program for farmers was a 1975-1978 project titled "Dealing With Risk in Farm Decision Making." Through this project, extension personnel at OlJahoma State University, Oregon State University, and other land-grant institutions developed and tested an extensive set of instructional materials, which were made available to extension economists in all states. A second "early initiative in risk management education was the Federal Crop Insurance Corporation's formation, in 1982, of an extension advisory committee, through which it supports risk management educational activities.

Since the early 1980 s, risk considerations have been incorporated into educational programs at an accelerating pace. Advances in computing technology have facilitated this progress by allowing introduction of analytical methods, such as Monte Carlo simulation, into software packages developed to serve as managerial decision aids and support educational programs. Aside from the significant influence of these technical innovations, several factors have contributed to increased application of risk analysis techniques. Primary among these factors is an increased need for such analysis created by $(a)$ greater policy emphasis on an expanding set of alternative federally subsidized crop insurance products, (b) introduction of commodity options and a broad range of new alternative forward contracting mechanisms, and $(c)$ the possible risk increasing effects of trade liberalization and the FAIR Act.

\section{Prior Studies}

Although risk management has been a focus of educational programs for approximately 20 years, the body of literature addressing risk management educational issues is scant. Papers by Nelson and Harris and Holt and Anderson described early efforts in development and delivery of extension educational programs placing primary emphasis on risk analysis. More recent studies by Anderson and 
Mapp and Selley and Wilson have explored agricultural economists' perspectives on a range of issues relating to the effectiveness of risk management educational programs. Anderson and Mapp conducted in-depth interviews with extension economists experienced in risk management education. A theme that runs throughout their qualitative analysis of the interview responses is that the participating educators found risk management a challenging topic to "sell" to agricultural producers. Selley and Wilson conducted a national survey of agricultural economists involved in risk management research and extension. In general, their results supported Anderson and Mapp's findings regarding economists' perceptions that producers showed limited receptiveness to risk management programs. Goodwin and Schroeder used data from a 1992 survey of Kansas Farm Management Association members to investigate factors affecting participation in marketing/risk management educational programs and adoption of forward-pricing methods. Binomial probit models examined educational program participation decisions, with results indicating that the probability of participation increased with farm size, years of education, the proportion of total farm acres in crops, and financial leverage (measured by the debt-to-asset ratio). Producers who expressed a preference for business risk were also significantly more likely to attend, as were farmers who spent more hours per week reading farm publications. Factors associated with decreased educational program participation were years of professional farming experience and distance from the farm to the nearest town.

In summary, the literature to date raises questions regarding the likely success of risk management educational programs. Although early studies (Nelson and Harris; Holt and Anderson) reported successful experience in risk management educational efforts, more recent studies (Anderson and Mapp; Selley and Wilson) have revealed that many educators have not found producer audiences receptive to risk management training. Importantly, all of these studies, as well as that of Goodwin and Schroeder, were conducted prior to the signif- icant farm and trade policy changes of the latter half of the 1990s. Thus changes in the business environment may have increased producers' interest in risk management, so that future educational initiatives will be better received and achieve greater success. The survey results and analysis reported in the remainder of this paper are intended to illuminate this issue.

\section{Conceptual Framework}

Goodwin and Schroeder propose Ben-Porath's model of human capital investment as an appropriate framework for evaluating educational program participation. In this model, the production function through which an individual invests in human capital is given by

\section{(1) $Q_{t}=\beta_{0}\left(s_{t} K_{t}\right)^{\beta_{1}} D_{t}^{\beta}=$}

where $Q_{t}$ is the quantity of human capital produced in time period $t ; K_{t}$ is the current stock of human capital; $s_{t}\left(0 \leq s_{t} \leq 1\right)$ is the proportion of time devoted to human capital production versus production of market goods; $D_{s}$ is the quantity of purchased inputs devoted to human capital production; and $\beta_{0}, \beta_{1}$, and $\beta_{2}$ are parameters. Human capital augmentation or net human capital investment in any time period, which may be positive, zero, or negative, is given by

\section{(2) $\dot{K}_{\imath}=Q_{\imath}-\delta K_{r}$}

where $\dot{K}_{t}$ is the derivative of $K_{t}$ with respect to $t$, and $\delta$ is the rate at which human capital deteriorates. Investment cost is expressed as

$$
I_{\mathrm{f}}=\alpha_{v^{3}} S_{\mathrm{t}} K_{\mathrm{t}}+P_{d d} D_{\mathrm{r}}
$$

where $\alpha_{0}$ is the rental rate on human capital (i.e., the value of a unit of human capital in the production of market goods), and $P_{d}$ is the price of the purchased input. The minimum cost of any level of human capital investment is obtained by minimizing Equation (3) subject to Equation (1). From this, marginal cost is derived and equated to the associated marginal benefit-which is equal to the discount- 
ed net return from the capital investment at rental rate $\alpha_{0}$ and interest rate $r$ over the remainder of the planning horizon-to obtain Equation (4) as an expression for optimal production of human capital in any time period.

$$
\begin{aligned}
Q_{t}= & \beta_{0}\left(\frac{\beta_{0} \beta_{1}}{r+\delta}\right)^{\left(\beta_{1}+\beta_{2}\right) /\left(1-\beta_{1}-\beta_{2}\right)}\left(\frac{\beta_{2} \alpha_{0}}{\beta_{1} P_{d}}\right)^{\beta_{2}\left(1-\beta_{1}-\beta_{2}\right)} \\
& \times\left[1-e^{-(r+\delta)(r-t)}\right]^{\left(\beta_{1}+\beta_{3}\right) /\left(t-\beta_{1}+\beta_{3}\right)} .
\end{aligned}
$$

A primary implication of the result in Equation (4) for educational program participation is that optimal investment depends on the length of planning horizon, $T-t$, such that investment decreases as an individual approaches retirement (note that in Equation [4] $Q_{r}=0$ ). It can also easily be shown that $Q_{t}$ increases in the parameters of the production function $\left(\beta_{1}, \beta_{2}\right.$, and $\left.\beta_{3}\right)$. This indicates that, ceteris paribus, an individual with greater inherent learning ability, as reflected in larger values of these parameters, will invest more heavily in the production of human capital. Further, if general education such as college or prior training in a specific subject matter area enhances learning efficiency through an increase in one or more of these parameters, then optimal investment will be increased.

\section{Survey States, Procedures, and Responses}

The four states participating in our project are Indiana, Mississippi, Nebraska, and Texas. ${ }^{3} \mathrm{~A}$

\footnotetext{
${ }^{3}$ The survey targeted producers of major field crops: specifically com and soybeans in Indiana and Nebraska, cotton and soybeans in Mississippi, and cotton and grain sorghum in Texas. These states were chosen in part because scientists at land grant institutions in eacl state were collaborating in the study. Importantly, however, crop agriculture in these states is representative of the Midwest (Indiana and eastern Nebraska), the Central and Southern Great Plains (western Nebraska and Texas), and Mississippi Delta (Mississippi)-four major U.S. field crop production regions. The possibility of a national survey was considered. However, the resources available for the survey would not have allowed sufficiently dense sampling at the national level to support much of the analysis that was planned to be conducted with the survey data. Sections of the questionnaire focused on general farm business and farm operator characteristics, perceptions of risk and usefulness of alternative
}

survey of crop producers was conducted in these states during March and April of 1999. Survey questionnaires were developed by the collaborating project investigators in cooperation with a National Agricultural Statistical Service (NASS) survey specialist and other agricultural statisticians in the four state NASS offices. During this process, the questionnaires were reviewed by agricultural economists and members of the project's advisory committee. Clarity of the questions was further strengthened through individual and group sessions in which agricultural producers completed the questionnaire, commenting on any questions they found ambiguous, difficult to answer, or otherwise problematic.

NASS databases were utilized to generate stratified random samples of farms for inciusion in the survey mailings. ${ }^{*} \mathrm{~A}$ complete design type process was followed by the state NASS offices in conducting the survey. Initial mailings included the survey questionnaire and a cover letter that solicited participation and offered assurance of respondent confidentiality. This was followed by a postcard re-

risk management practices, agricultural policy preferences, and risk management educational needs. All data utilized in this study come from the general information and risk management education sections of the questionnaire which were identical for all states, or from questions in other sections that were not statespecific.

+ Stratum designations were based on NASS estimated gross farm revenue for the previous year, with four size strata defined for revenue ranges of $\$ 25,000-$ $\$ 99,999$ (size stratum 1); $\$ 100,000-\$ 249,999$ (size stratum 2); $\$ 250,000-\$ 499,999$ (size stratum 3); and $\$ 500,000$ or more (size stratum 4 ). Of 1,304 survey participants whose responses were sufficiently complete for inclusion in our analysis, the distribution by size stratum (percent in each size stratum) was as follows: size stratum 1, 25.5\%; size stratum 2, 29.0\%; size stratum 3,17.1\%; and size stratum 4, 28.4\%. For Indiana the distribution across size strata was size stratum 1, 21.0\%; size stralum 2, 22.2\%; size stratum 3, $25.1 \%$; and size stratum $4,31.7 \%$. The size stratum distribution for Mississippi was size stratum 1, 9.5\%; size stratum 2, 22.8\%; size stratum 3, 27.2\%; and size stratum $4,40.5 \%$. For Nebraska the distribution was size stratum $1,12.6 \%$; size stratum $2,27.0 \%$; size stratum 3, 30.6\%; and size stratum 4, 29.7\%. And for Texas the distribution was size stratum $1,21.1 \%$; size straturn 2, 22.4\%; size stratum 3,22.7\%; and size stratum $4,33.8 \%$. 
minder in approximately 2 weeks. A second copy of the questionnaire and cover letter were mailed to all nonrespondents after a similar time interval. A total of 6,810 farms were included in the initial mailing. A total of 1,812 useable questionnaires were returned, for a response rate of $26.6 \%$. Of the returned surveys, 1,304 are incorporated into our analysis, based on completeness of all pertinent information.

\section{Past Educational Program Participation and the Role of Extension Personnel}

In this section, we summarize survey results regarding past risk management educational program participation. Educational programs in three subject matter areas-marketing, crop yield and revenue insurance, and financial management-are separately considered. Issues examined include ( $a$ ) whether respondents participated in educational programs in the subject matter area during the past 3 years, (b) number of hours of training completed by educational program participants, and $(c)$ the instructional role of extension personnel in those programs. Results are summarized by farm operator age strata, because of the central role of age or length of planning horizon in human capital investment decisions. ${ }^{5}$ To facilitate concise presentation, stratum means are reported graphically in Figure 1. Also summarized are results of $t$-tests for statistical significance of differences in strata means.

Responses regarding educational program participation rates during the past 3 years are

\footnotetext{
${ }^{5}$ It is appropriate to further clarify the reasons underlying the reporting format chosen. Size (estimated income) stratification was used in sampling not because farm size was considered the factor of central interest, but because it was necessary in order to obtain a sample with substantial representation of all but the smallest farms, which would predominate with nonstratified random sampling. The results are summarized by age strata because age is the best proxy available for length of planning horizon that, as cliscussed in the previous section, is expected to play a central role in human capital investment decisions. The overall percentage of respondents in each of the age strata was reasonably uniform: stratum 1 (operator age 40 and under), 19.5\%; stratum 2 (operator age 41-50), 32.9\%; stratum 3 (operator age $5 l-60$ ), 27.0\%; and stratum 4 (operator age over 60), $20.6 \%$.
}

presented in panel (a) of Figure 1. These results indicate substantially higher participation in marketing programs than in programs on crop yield and revenue insurance or financial management. Patterns of participation in marketing and financial management programs across age strata are consistent with the implications of Ben-Porath's model: participation decreases with farm operator age. However, a similar pattern of participation is not revealed for educational programs focusing on crop yield and revenue insurance. A possible explanation for this result is that information on frequently changing federally subsidized insurance programs is considered to have a relatively short useful life. This may have an equalizing effect on valuation of this information by farmers of different ages. ${ }^{6}$

Average hours of training for educational program participants is presented in panel (b) of Figure 1. Marketing program participants indicate having engaged in a substantial amount of training-approximately 13 to 16 hours over the past 3 years-with no significant differences among the age strata. Crop yield and revenue insurance program participants engaged in fewer hours of trainingfrom 4 to 7 hours-with no clear pattern in differences among age groups. Like marketing program participants, farm operators who attended educational programs on financial management completed a substantial number of hours of training. The pattern in hours of training across age strata is similar to the pattern in program participation, with the exception of farm operators in the youngest age stratum who were more likely to participate in financial management programs but report having engaged in fewer hours of training than farm operators in age strata 2 and 3 .

The questions summarized in panel (c) of Figure I asked education program participants

${ }^{6}$ An extreme example of what we are describing would be an insurance program with provisions that are completely changed every year, such that, in the context of Ben-Porath's model, information on the program obtained in period $t$ has value in year $t+1$ only. All else equal, this information would be valued equally by all producers except those in their retirement year (time period $T$ ), for whom it would have no value. 

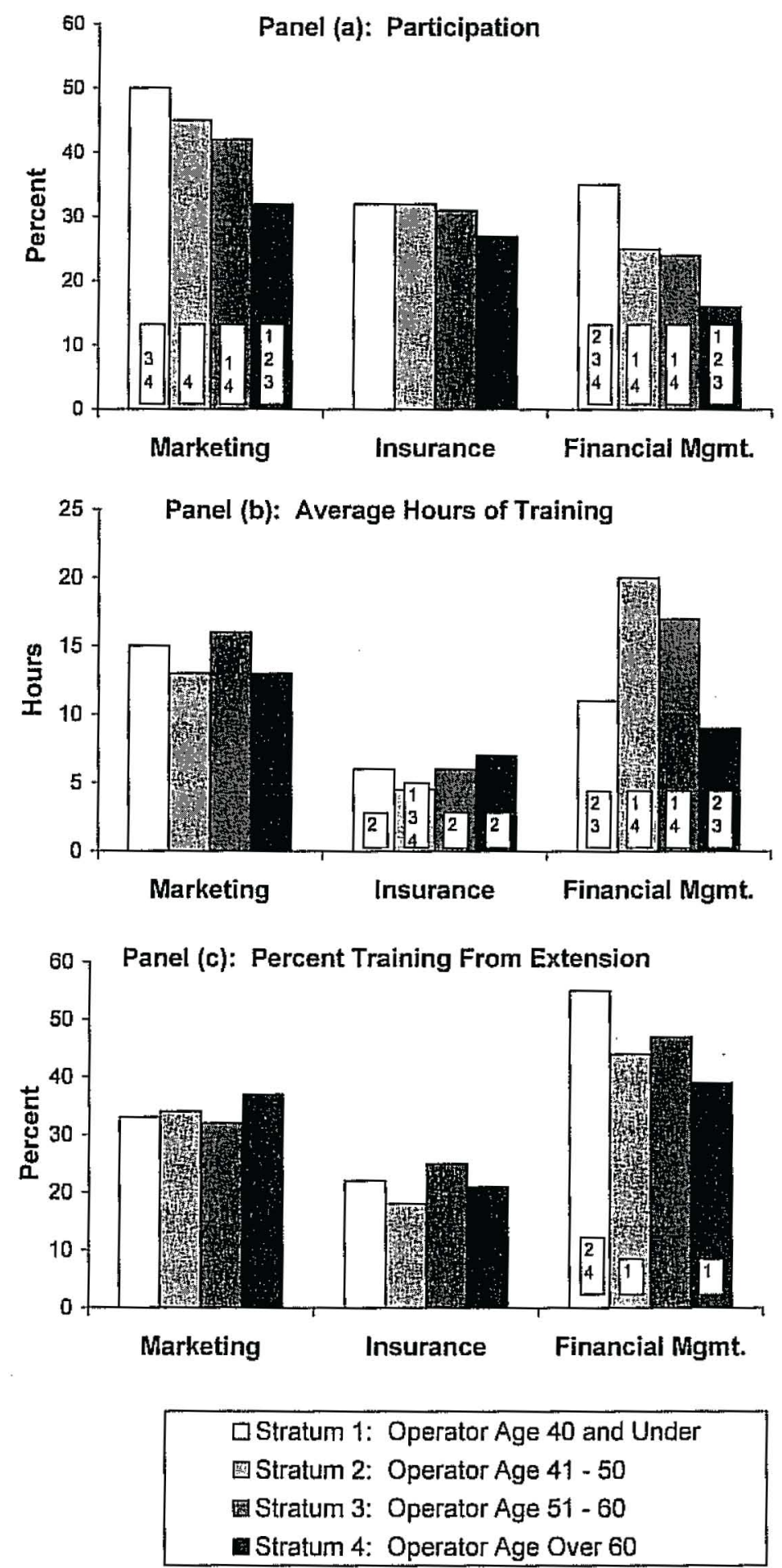

Figure 1. Participation in Educational Programs in the Past 3 Years, Average Hours of Training, and Percent of Training from Extension (Numbers inside bars identify strata with means that are significantly different, at the $5 \%$ level, than the mean for that stratum.) 


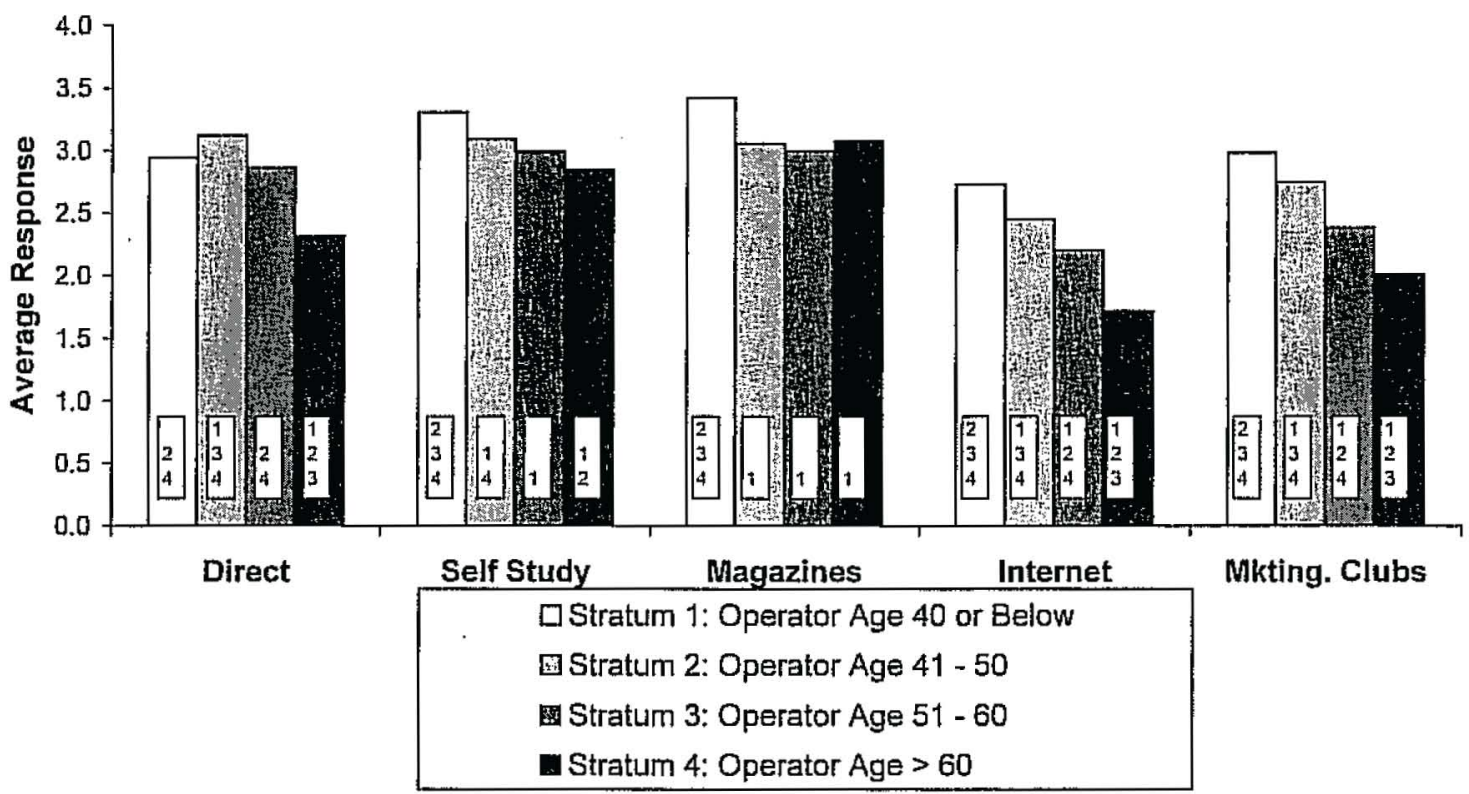

Figure 2. Rating of Methods for Learning about Risk Management Tools by Farm Operator Age (response scale 1-5)

what proportion of the instruction they received was conducted by extension personnel. Recognizing educational programs are organized, sponsored, and conducted with resources and personnel from various combinations of public and private organizations, the purpose of this line of questioning was to gain a perspective on the teaching role of extension personnel in recent risk management educational programs. Results show that extension's role was largest in financial management programs, at more than $40 \%$ for all age groups, and smallest for crop yield and revenue insurance programs, ranging from $18 \%$ to $25 \%$. Differences among age groups are not statistically significant for either marketing or insurance programs. The greater role of extension personnel in financial management programs attended by farmers in the youngest age stratum is significantly different than the indicated role of extension in programs attended by farmers in age strata 2 and 4 , but not stratum 3 .

\section{Rating of Methods for Learning About Risk Management Tools}

Responses to the question "How do you prefer to learn about risk management tools?" are summarized in Figure 2. A 5-point ( 1 to 5) Likert-type response model was used for this question (Likert), with responses at the lower end of the range defined as indicating "low preference" and responses at the upper end of the range indicating "strong preference" for the learning method. Average responses for "in-depth training by risk management experts" (referred to in Figure 2 as Direct) range from 2.3 for age stratum 4 to 3.1 for stratum 2. With the exception of age stratum 1 , the ratings decline with farm operator age. "Indepth materials to study on your own time" (Self-Study) is rated somewhat higher, ranging from 2.8 for age stratum 4 to 3.3 for stratum 1 , and declines uniformly, although modestly, with age. Materials in the category "farm magazines/newsletters" (Magazines) are also rated relatively highly by all age groups, with a range from 3.0 for age stratum 3 to 3.4 for age stratum 1. Differences in ratings for all ages except the youngest group of farm operators are not statistically significant. "Internet or other computer-based education modules" (Internet) and "marketing clubs or other groups of producers" (Mkting. Clubs) rate lower and show a stronger pattern of preference across age strata, with younger farm op- 
erators showing greater receptiveness to these learning methods.

\section{Analysis of Desire for Additional Risk Management Education}

Given the central role risk would be expected to play in decisions regarding risk management educational program participation, Goodwin and Schroeder proposed evaluating those decisions in a random utility framework, such that a farm operator chooses to participate in an educational program if expected utility with the training exceeds expected utility without additional training. Our models of expressed strong interest in additional training are similarly motivated. In this section, we first describe the construction of the variables incorporated into our analysis and provide summary statistics on those variables. Then we present our probit model results examining factors affecting desire for additional risk management training. In discussing these results, we focus on marginal effects, which are of primary interest.

\section{Data}

Data used in our analysis were obtained through the survey described earlier. Definitions of variables are provided in Table 1 , and summary statistics are given in Table 2. Dichotomous dependent variables were constructed to distinguish respondents who expressed strong interest in additional education in the five subject matter areas-forward contracting, futures and options, crop yield insurance, crop revenue insurance, and financial management-from respondents who did not. As indicated in Table 2, roughly half of survey respondents express strong interest in additional education on forward contracting, futures and options, and financial management. Approximately $40 \%$ of respondents express strong interest in educational programs on crop yield insurance and crop revenue insurance.

Of the explanatory variables included in our models, operator age follows most directly from Ben-Porath's conceptual model. Al- though years to planned retirement $(T-t)$ would be the ideal measure of length of planing horizon, many applied studies of producer response to risk use age (Asplund, Forster, and Stout; Goodwin and Schroeder; Shapiro and Brorsen). Goodwin and Schroeder reported obtaining almost identical results in alternative models utilizing age and farming experience to capture this effect. Their results showed an expected negative effect of these variables on the probability of marketing educational program participation. College, prior training, and prior use of the practice are also motivated by Ben-Porath's model. As discussed earlier, college and prior training might increase learning efficiency. If so, they would be expected to increase the probability of educational program participation or, in our models, the probability of strong interest in additional training. Consistent with this, Goodwin and Schroeder's empirical results showed a positive effect of years of formal education on educational program participation. Prior use of the practice is included to reflect past human capital enhancement gained through experience.

Other variables included in the models affect the risk environment, the relationship between expected benefits and opportunity cost of human capital investment, or both. Operators of large farms, as reflected in cropland acres, would balance costs of human capital investment against larger potential benefits; however, the opportunity cost of time spent in educational programs could also be higher. Therefore, a priori expectations about the sign of this variable are not strongly supported. Diversification of sources of income through offfarm employment (off-farm income) might reduce income risk and substitute for use of risk management practices in the farming operation. If so, this should reduce the probability of risk management educational program participation. Goodwin and Schroeder's empirical results suggest that producers with weaker equity positions (higher percent borrowed) might be expected to place higher value on risk management training. Producers whose lenders recommend use of a risk management practice (recommended by lender) might re- 
Table 1. Definition of Variables

\begin{tabular}{ll}
\hline Variable & \multicolumn{1}{c}{ Definition } \\
\hline Strong interest & Dummy variables equal to 1 if the respondent rated his/her interest \\
& in additional education in use of each of five risk management \\
practices as a 4 or 5 on a $1-5$ scale, with lower responses indicat- & ing "low interest" and higher responses indicating "strong inter- \\
est"
\end{tabular}

Operator age

College

Prior training

Prior use

Cropland acres

Off-farm income

Percent borrowed

Recommended by lender

High price risk

High yield risk

Risk avoidance

Proportion corn/cotton/grain sorghum/soybeans/wheat
Age of primary farm operator

Dummy variable indicating at least some college education

Hours of training in use of the risk management practice during the past 3 years (hours of training in forward contracting, futures, and options were combined in a single question as were prior training in crop yield and revenue insurance)

Dummy variable indicating that the risk management practice was used during the past 3 years

Acres of cropland in the farming operation

Expected percent of 1999 household gross income from off-farm employment

Percent of total farm investment borrowed

Dummy variable indicating that the respondent's primary lender recommends use of the risk management practice

Dummy variable indicating respondent rated the potential effect of crop price variability on his/her farm income as a 4 or 5 on a 1-5 scale, with lower responses indicating "low potential effect" and higher responses indicating "high potential effect"

Dummy variable indicating respondent rated the potential effect of crop yield variability on his/her farm income as a 4 or 5 on a 1-5 scale, with lower tesponses indicating "low potential effect" and higher responses indicating "high potential effect"

Dummy variable identifying respondents who indicated a willingness to accept a lower price to reduce price risk

Variables indicating proportion of total 1999 crop acreage expected to be planted to each of these crops alize benefits of an increased line of credit by using the practice. Thus they have additional incentive to participate in educational programs to support effective use of recommended practices. Following Goodwin and Schroeder's random utility formulation, risk effects are incorporated into our models through high price risk, high yield risk, and risk avoidance. Risk averse producers who perceive price or yield risk as having high potential effect on their income would be expected to place increased priority on educational programs focusing on management of those risks. Because of difficulties in obtaining reliable measures of risk aversion through responses to a mail sur- vey, we used expressed willingness to accept a lower price in order to reduce price risk as a general indicator of priority placed on risk reduction (risk avoidance). Proportions of crop acres in the five major crops are included in the models to account for effects of cropspecific factors on educational program interest. ${ }^{7}$

\footnotetext{
${ }^{7}$ Corn and cotton can be used to illustrate some crop-specific factors that might account for differences in educational program interest. During the period 1995-1999, at the national level, the Actual Production History (APH) program crop insurance loss ratio (inclemnities paid $\div$ premiums) for corn was 0.73 versus 1.41 for cotton. Thus unintended differences in the ac-
} 


\section{Results}

Our probit model results are summarized in Table 3. Operator age has the expected negative sign and is statistically significant at the $10 \%$ level in models of desire for training in use of forward contracting, futures and options, and financial management. Consistent with historical educational program participation patterns presented in panel (a) of Figure 1, operator age does not have a statistically significant effect on desire for additional training in the areas of crop yield and revenue insurance. As observed earlier, this might be a consequence of a perception that the useful life of information about these changing government programs is short enough so that the information is similarly valued by producers of all ages. A perspective on magnitudes of the marginal effects of operator age, in the models where those effects are significant, can be gained by considering estimated differences in probabilities of expressing strong interest in those educational areas for the youngest and oldest age strata defined earlier (i.e., 40 years and under versus over 60 years of age). Approximately $20 \%$ of producers surveyed are in each of these strata, and the difference in median ages of producers in the two strata is 31 years (i.e., 36 for stratum 1 and 67 for stratum 4). Our results indicate that the effect of this difference is that producers in the younger age group have $7.0 \%$ greater probability of expressing strong interest in additional training in forward contracting compared with $16.4 \%$ for futures and options and $14.4 \%$ for financial management.

tuarial performance of insurance programs for these two crops provide different incentives for insurance program participation and might be expected to result in different levels of interest in educational programs designed to help make informed choices among available insurance products and coverage options. (It should be noted that statutory target loss ratios are equal, at 1.075, for all crops.) Also, there are significant differences in customary marketing practices for the two crops. A substantial proportion of cotton is marketed through professionally managed pooling arrangements, whereas most corn is marketed directly by farmers. This difference clearly could influence producers' interest in educational programs on forward contracting and futures and options.
Table 2. Summary Statistics on Variables Included in Probit Models

\begin{tabular}{lrr}
\hline Variable & \multicolumn{1}{c}{$M$} & \multicolumn{1}{c}{ SD } \\
\hline Strong interest in & & \\
$\quad$ Forward contracting & 0.50 & 0.50 \\
Futures and options & 0.52 & 0.50 \\
Crop yield insurance & 0.38 & 0.51 \\
Crop revenue insurance & 0.40 & 0.51 \\
Financial management & 0.53 & 0.50 \\
Operator age & 51.69 & 11.63 \\
College & 0.68 & 0.47 \\
Prior training & & \\
Forward contracting, & & \\
$\quad$ futures, and options & 5.96 & 15.42 \\
Crop yield and & & \\
$\quad$ reventue insurance & 1.74 & 4.93 \\
Prior use of & & \\
Forward contracting & 0.61 & 0.49 \\
Futures and options & 0.32 & 0.47 \\
Crop yield insurance & 0.48 & 0.50 \\
Crop revenue insurance & 0.17 & 0.37 \\
Financial management & $\mathrm{NA}$ & $\mathrm{NA}$ \\
Cropland acres & $1,486.73$ & $1,590.59$ \\
Off-farm income & 20.23 & 27.50 \\
Percent borrowed & 39.61 & 32.78 \\
Recommended by lender & & \\
Forward contracting, & & \\
$\quad$ futures, and options & 0.31 & 0.46 \\
$\quad$ Crop yield and & & \\
$\quad$ revenue insurance & 0.47 & 0.50 \\
High yrice risk & 0.94 & 0.23 \\
Risk avoidance & 0.78 & 0.41 \\
Proportion corn & 0.35 & 0.48 \\
Proportion cotton & 0.26 & 0.27 \\
Proportion grain sorghum & 0.23 & 0.34 \\
Proportion soybeans & 0.06 & 0.16 \\
Proportion wheat & 0.31 & 0.31 \\
\hline Surveld & 0.07 & 0.15 \\
\hline
\end{tabular}

"Survey did not elicit information on prior use of financial management becnuse "use of" financial management is ill-defined as compared with use of the other rish management practices examined.

College is significant in models for educational programs on futures and options, crop revenue insurance, and financial management. Estimated marginal effects indicate that having completed at least some college increases the probability of strong interest in futures and options training by $9.3 \%$, compared with $6.8 \%$ 
Table 3. Probit Models of Strong Interest in Additional Risk Managenent Education

\begin{tabular}{|c|c|c|c|c|c|c|c|c|c|c|}
\hline \multirow[b]{2}{*}{ Variable } & \multicolumn{2}{|c|}{ Forward Contracting } & \multicolumn{2}{|c|}{ Futures and Options } & \multicolumn{2}{|c|}{ Yield Insurance } & \multicolumn{2}{|c|}{ Revenue Insurance } & \multicolumn{2}{|c|}{ Financial Management } \\
\hline & Estimate & $\begin{array}{l}\text { Marginal } \\
\text { Effect }{ }^{\mathrm{t}}\end{array}$ & Estimate & $\begin{array}{l}\text { Marginal } \\
\text { Effect }{ }^{p}\end{array}$ & Estimate & $\begin{array}{l}\text { Marginal } \\
\text { Effect }\end{array}$ & Estimate & $\begin{array}{c}\text { Marginal } \\
\text { Effect }^{a}\end{array}$ & Estimate & $\begin{array}{l}\text { Marginal } \\
\text { Effect }^{\mathrm{a}}\end{array}$ \\
\hline Intercept & $\begin{array}{l}-0.8669^{\prime: 4} \\
(0.3691)\end{array}$ & & $\begin{array}{c}-0.2683 \\
(0.3722)\end{array}$ & & $\begin{array}{c}-1.8786^{*} \\
(0.3865)\end{array}$ & & $\begin{array}{c}-1.9983^{*} \\
(0.3836)\end{array}$ & & $\begin{array}{c}-0.3420 \\
(0.3731)\end{array}$ & \\
\hline Operator age & $\begin{array}{c}-0.0056^{*} \\
(0.0034)\end{array}$ & $\begin{array}{c}-0.2250^{\sharp} \\
(0.1339)\end{array}$ & $\begin{array}{c}-0.0133^{*} \\
(0.0034)\end{array}$ & $\begin{array}{c}-0.5306^{14} \\
(0.1356)\end{array}$ & $\begin{array}{c}0.0029 \\
(0.0035)\end{array}$ & $\begin{array}{c}0.1115 \\
(0.1310)\end{array}$ & $\begin{array}{c}0.0015 \\
(0.0035)\end{array}$ & $\begin{array}{c}0.0561 \\
(0.1313)\end{array}$ & $\begin{array}{c}-0.0117^{\mathrm{k}} \\
(0.0034)\end{array}$ & $\begin{array}{r}-0.4636^{\prime 14} \\
(0.1362)\end{array}$ \\
\hline College & $\begin{array}{c}0.1059 \\
(0.0815)\end{array}$ & $\begin{array}{c}4.2225 \\
(3.2494)\end{array}$ & $\begin{array}{c}0.2342^{* \mid *} \\
(0.0821)\end{array}$ & $\begin{array}{c}9.3294^{*} \\
(3.2729)\end{array}$ & $\begin{array}{c}0.0705 \\
(0.0848)\end{array}$ & $\begin{array}{c}2.6657 \\
(3.2071)\end{array}$ & $\begin{array}{r}0.1766^{+1} \\
\cdot(0.0845)\end{array}$ & $\begin{array}{l}6.7796^{*} \\
(3.2420)\end{array}$ & $\begin{array}{c}0.1979^{*} \\
(0.0821)\end{array}$ & $\begin{array}{l}7.8597^{*} \\
(3.2600)\end{array}$ \\
\hline Prior training & $\begin{array}{c}0.0026 \\
(0.0022)\end{array}$ & $\begin{array}{c}0.1048 \\
(0.0891)\end{array}$ & $\begin{array}{c}0.0064^{*} \\
(0.0024)\end{array}$ & $\begin{array}{c}0.2555^{*} \\
(0.0941)\end{array}$ & $\begin{array}{c}0.0238 * \\
(0.0077)\end{array}$ & $\begin{array}{c}0.9019^{*} \\
(0.2930)\end{array}$ & $\begin{array}{c}0.0233^{*} \\
(0.0080)\end{array}$ & $\begin{array}{c}0.8954^{*} \\
(0.3088)\end{array}$ & $\begin{array}{c}0.0228 \\
(0.0050)\end{array}$ & $\begin{array}{r}0.9053^{\text {* }} \\
(0.1980)\end{array}$ \\
\hline Prior use & $\begin{array}{c}0.3771^{* 1} \\
(0.0811)\end{array}$ & $\begin{array}{l}15.0402^{4} \\
(3.2350)\end{array}$ & $\begin{array}{c}0.1801^{*} \\
(0.0818)\end{array}$ & $\begin{array}{l}7.1758^{*} \\
(3.2576)\end{array}$ & $\begin{array}{r}0.2499 * \\
(0.0806)\end{array}$ & $\begin{array}{c}9.4540^{\mathrm{k}} \\
(3.0478)\end{array}$ & $\begin{array}{c}0.3361^{\text {J }} \\
(0.1023)\end{array}$ & $\begin{array}{l}12.9040^{*} \\
(3.9285)\end{array}$ & $\mathrm{NA}^{\mathrm{c}}$ & $\mathrm{NA}^{\mathrm{E}}$ \\
\hline $\begin{array}{c}\text { Cropland acres } \\
\text { (thousands) }\end{array}$ & $\begin{array}{c}0.0138 \\
(0.0240)\end{array}$ & $\begin{array}{c}0.5523 \\
(0.9656)\end{array}$ & $\begin{array}{c}0.0334 \\
(0.0243)\end{array}$ & $\begin{array}{c}1.3298 \\
(0.9673)\end{array}$ & $\begin{array}{r}0.02673 \\
(0.0245)\end{array}$ & $\begin{array}{c}1.0111 \\
(0.9282)\end{array}$ & $\begin{array}{c}0.0628^{*} \\
(0.0247)\end{array}$ & $\begin{array}{c}2.4103^{4} \\
(0.94913)\end{array}$ & $\begin{array}{c}0.0892^{*} \\
(0.0254)\end{array}$ & $\begin{array}{r}3.5416^{4} \\
(1.0104)\end{array}$ \\
\hline Off-farm income & $\begin{array}{c}0.0019 \\
(0.0014)\end{array}$ & $\begin{array}{c}0.0755 \\
(0.0554)\end{array}$ & $\begin{array}{c}0.0019 \\
(0.0014)\end{array}$ & $\begin{array}{c}0.0751 \\
(0.0560)\end{array}$ & $\begin{array}{c}-0.0022 \\
(0.0015)\end{array}$ & $\begin{array}{c}-0.0835 \\
(0.0562)\end{array}$ & $\begin{array}{c}-0.0021 \\
(0.0015)\end{array}$ & $\begin{array}{c}-0.0802 \\
(0.0566)\end{array}$ & $\begin{array}{c}-0.0022 \\
(0.0014)\end{array}$ & $\begin{array}{c}-0.0875 \\
(0.0565)\end{array}$ \\
\hline Percent borrowed & $\begin{array}{c}0.0032 * \\
(0.0012)\end{array}$ & $\begin{array}{c}0.1291^{*} \\
(0.0481)\end{array}$ & $\begin{array}{c}0.0045^{*} \\
(0.0012)\end{array}$ & $\begin{array}{c}0.1791^{*} \\
(0.0486)\end{array}$ & $\begin{array}{c}0.0032^{*} \\
(0.0013)\end{array}$ & $\begin{array}{c}0.1210^{*} \\
(0.0473)\end{array}$ & $\begin{array}{c}0.0033^{*} \\
(0.0013)\end{array}$ & $\begin{array}{c}0.1273 * \\
(0.0480)\end{array}$ & $\begin{array}{c}0.0056 \% \\
(0.0012)\end{array}$ & $\begin{array}{r}0.2206^{*} \\
(0.0479)\end{array}$ \\
\hline $\begin{array}{l}\text { Recommended } \\
\text { by lender }\end{array}$ & $\begin{array}{c}0.2378^{*} \\
(0.0810)\end{array}$ & $\begin{array}{c}9.4856^{\text {* }} \\
(3.2309)\end{array}$ & $\begin{array}{c}0.3380^{\prime \prime} \\
(0.0822)\end{array}$ & $\begin{array}{l}13.4648^{\text {tk }} \\
(3.2750)\end{array}$ & $\begin{array}{c}0.3462^{4} \\
(0.0821)\end{array}$ & $\begin{array}{l}13.0960^{\sharp} \\
(3.1040)\end{array}$ & $\begin{array}{c}0.3481^{4} \\
(0.0798)\end{array}$ & $\begin{array}{l}13.3659^{*} \\
(3.0634)\end{array}$ & $N A^{c}$ & $\mathrm{NA}^{c}$ \\
\hline High price risk & $\begin{array}{c}0.5081^{*} \\
(0.1737)\end{array}$ & $\begin{array}{l}20.2679^{\text {th }} \\
(6.9287)\end{array}$ & $\begin{array}{c}0.3077^{\text {t }} \\
(0.1710)\end{array}$ & $\begin{array}{l}12.2574^{\text {th }} \\
(6.8148)\end{array}$ & $\begin{array}{c}0.3071^{* k} \\
(0.1805)\end{array}$ & $\begin{array}{l}11.6176^{*} \\
(0.0826)\end{array}$ & $\begin{array}{c}0.3259^{*} \\
(0.1778)\end{array}$ & $\begin{array}{l}12.5116^{*} \\
(6.8226)\end{array}$ & $\begin{array}{c}0.4903^{* *} \\
(0.1706)\end{array}$ & $\begin{array}{l}19.4769 * \\
(6.7785)\end{array}$ \\
\hline High yield risk & $\begin{array}{c}0.1156 \\
(0.0913)\end{array}$ & $\begin{array}{c}4.6098 \\
(3.6421)\end{array}$ & $\begin{array}{c}0.0744 \\
(0.0931)\end{array}$ & $\begin{array}{c}2.9635 \\
(3.7123)\end{array}$ & $\begin{array}{c}0.2350^{*} \\
(0.0966)\end{array}$ & $\begin{array}{c}8.8909^{*} \\
(3.6510)\end{array}$ & $\begin{array}{c}0.1933^{*} \\
(0.0958)\end{array}$ & $\begin{array}{c}7.4214^{*} \\
(3.6764)\end{array}$ & $\begin{array}{c}0.1048 \\
(0.0923)\end{array}$ & $\begin{array}{c}4.1615 \\
(3.6663)\end{array}$ \\
\hline Risk avoidance & $\begin{array}{c}0.1170 \\
(0.7603)\end{array}$ & $\begin{array}{c}4.6675 \\
(3.0327)\end{array}$ & $\begin{array}{c}0.2278^{*} \\
(0.0769)\end{array}$ & $\begin{array}{c}9.0773^{*} \\
(3.0652)\end{array}$ & $\begin{array}{c}0.3347^{*} \\
(0.0775)\end{array}$ & $\begin{array}{l}11.9028^{*} \\
(2.9294)\end{array}$ & $\begin{array}{c}0.2814 * \\
(0.0774)\end{array}$ & $\begin{array}{l}10.8036^{*} \\
(2.9692)\end{array}$ & $\begin{array}{c}0.1379 * \\
(0.0769)\end{array}$ & $\begin{array}{r}5.4764 \\
(3.0566)\end{array}$ \\
\hline
\end{tabular}


Table 3. Continued

\begin{tabular}{|c|c|c|c|c|c|c|c|c|c|c|}
\hline \multirow[b]{2}{*}{ Variable } & \multicolumn{2}{|c|}{ Forward Contracting } & \multicolumn{2}{|c|}{ Futures and Options } & \multicolumn{2}{|c|}{ Yield Insurance } & \multicolumn{2}{|c|}{ Reventie Insurance } & \multicolumn{2}{|c|}{ Financial Management } \\
\hline & Estimate & $\begin{array}{l}\text { Marginal } \\
\text { Elfect }^{\mathrm{a}}\end{array}$ & Estimate & $\begin{array}{c}\text { Marginal } \\
\text { Effect }^{\mathfrak{n}}\end{array}$ & Estimate & $\begin{array}{l}\text { Marginal } \\
\text { Effect }^{\mathrm{a}}\end{array}$ & Estimate & $\begin{array}{l}\text { Marginal } \\
\text { Effect }^{\mathrm{n}}\end{array}$ & Estimate & $\begin{array}{l}\text { Marginal } \\
\text { Effect }{ }^{u}\end{array}$ \\
\hline Proportion corn & $\begin{array}{c}-0.1364 \\
(0.2883)\end{array}$ & $\begin{array}{l}-5.4408 \\
(11.5010)\end{array}$ & $\begin{array}{c}0.0237 \\
(0.2895)\end{array}$ & $\begin{array}{c}0.9444 \\
(11.5349)\end{array}$ & $\begin{array}{c}0.1300 \\
(0.2939)\end{array}$ & $\begin{array}{c}5.2945 \\
(11.1176)\end{array}$ & $\begin{array}{c}0.3725 \\
(0.2967)\end{array}$ & $\begin{array}{c}14.3015 \\
(11.3919)\end{array}$ & $\begin{array}{c}-0.1260 \\
(0.2895)\end{array}$ & $\begin{array}{l}-5.0057 \\
(11.5000)\end{array}$ \\
\hline Proportion cotton & $\begin{array}{c}-0.1192 \\
(0.2699)\end{array}$ & $\begin{array}{l}-4.7554 \\
(10.7676)\end{array}$ & $\begin{array}{c}-0.2269 \\
(0.2730)\end{array}$ & $\begin{array}{l}-9.0383 \\
(10.8761)\end{array}$ & $\begin{array}{c}0.5506^{* k} \\
(0.2792)\end{array}$ & $\begin{array}{c}20.8285^{\text {st }} \\
(10.5591)\end{array}$ & $\begin{array}{c}0.7030^{\text {th }} \\
(0.2792)\end{array}$ & $\begin{array}{c}26.9892 \\
(10.7182)\end{array}$ & $\begin{array}{c}-0.2369 \\
(0.2750)\end{array}$ & $\begin{array}{l}-9.4088 \\
(10.9254)\end{array}$ \\
\hline $\begin{array}{l}\text { Proportion grain } \\
\text { sorghum }\end{array}$ & $\begin{array}{c}-0.1305 \\
(0.3527)\end{array}$ & $\begin{array}{l}-5.2045 \\
(14.0701)\end{array}$ & $\begin{array}{c}-0.1395 \\
(0.3623)\end{array}$ & $\begin{array}{l}-5.5574 \\
(14.4354)\end{array}$ & $\begin{array}{c}0.1436 \\
(0.3623)\end{array}$ & $\begin{array}{c}5.4320 \\
(13.7072)\end{array}$ & $\begin{array}{c}0.3719 \\
(0.3652)\end{array}$ & $\begin{array}{c}14.2779 \\
(14.0183)\end{array}$ & $\begin{array}{c}-0.1719 \\
(0.3595)\end{array}$ & $\begin{array}{l}-6.8287 \\
(14.2788)\end{array}$ \\
\hline $\begin{array}{l}\text { Proportion } \\
\text { soybeans }\end{array}$ & $\begin{array}{c}0.0152 \\
(0.2917)\end{array}$ & $\begin{array}{r}0.6065 \\
(0.1163)\end{array}$ & $\begin{array}{c}-0.0179 \\
(0.2926)\end{array}$ & $\begin{array}{l}-0.7120 \\
(11.6595)\end{array}$ & $\begin{array}{c}0.3237 \\
(0.3019)\end{array}$ & $\begin{array}{c}12.2433 \\
(11.4189)\end{array}$ & $\begin{array}{c}0.6059^{*} \\
(0.3018)\end{array}$ & $\begin{array}{l}23.2624^{\prime \prime} \\
(11.5853)\end{array}$ & $\begin{array}{c}0.0175 \\
(0.2936)\end{array}$ & $\begin{array}{c}0.6959 \\
(11.6642)\end{array}$ \\
\hline Propottion wheat & $\begin{array}{c}0.1308 \\
(0.3690)\end{array}$ & $\begin{array}{c}5.2163 \\
(14.7196)\end{array}$ & $\begin{array}{c}-0.0564 \\
(0.3741)\end{array}$ & $\begin{array}{c}-2.2479 \\
(14.9085)\end{array}$ & $\begin{array}{c}0.6243^{*} \\
(0.3758)\end{array}$ & $\begin{array}{l}23.6142 * \\
(14.2151)\end{array}$ & $\begin{array}{c}0.6704^{* *} \\
(0.3812)\end{array}$ & $\begin{array}{l}25.7371^{\text {米 }} \\
(14.6358)\end{array}$ & $\begin{array}{c}-0.0184 \\
(0.3778)\end{array}$ & $\begin{array}{l}-0.7300 \\
(15.0057)\end{array}$ \\
\hline Model $\chi^{24}$ & $\begin{array}{c}109.70 \\
(0.0001)=\end{array}$ & & $\begin{array}{c}155.96 \\
(0.0001)^{e}\end{array}$ & & $\begin{array}{c}148.02 \\
(0.0001)=\end{array}$ & & $\begin{array}{c}137.32 \\
(0.0001)^{\circ}\end{array}$ & & $\begin{array}{c}151.74 \\
(0.0001)^{=}\end{array}$ & \\
\hline $\begin{array}{l}\text { McFadden's } R^{2 \mathrm{~d}} \\
\% \text { correct }\end{array}$ & 0.0607 & & 0.0867 & & 0.0860 & & 0.0791 & & 0.0857 & \\
\hline predictions & 61.6565 & & 64.8961 & & 66.4093 & & 65.2681 & & 64.6646 & \\
\hline
\end{tabular}

${ }^{2}$ Marginal effects reported are probability changes expressed as percentnges.

"Numbers in parentheses are asymptotic standard errors. An asterisk indicates statistical significance at the $\alpha=0.10$ or smaller level.

c Variable was not available for inclusion in the model.

"The $\chi^{2}$ test evaluates the null hypothesis that all parameters in the model except the intercept are equal to 0 . McFadden's $R^{2}$ is given by 1 minus the ratio of the unrestricted

to restricted log-likelihood function values.

- Numbers in parentheses are associated $\chi^{2}$ probabilities. 
for crop revenue insurance and $7.9 \%$ for financial management. Estimated effects of prior training are significant in models of futures and options, crop yield insurance, crop revenue insurance, and financial management. The magnitude of the effect for futures and options is a probability increase of $0.3 \%$ per hour of prior training, but is much larger for crop yield insurance, crop revenue insurance, and financial management at approximately $0.9 \%$ per hour of prior training. Our models indicate that producers who have recently used a risk management practice are more likely to want additional training relating to the practice. This can by seen in the result that prior use is significant in models for all four practices on which the information was available. Estimated marginal effects of prior use are large, indicating increases in probabilities of strong interest in future educational programs of $15.0 \%$ for forward contracting, $7.2 \%$ for futures and options, $9.5 \%$ for crop yield insurance, and $12.9 \%$ for crop revenue insurance.

Cropland acres is significant only in models for crop revenue insurance and financial management. Marginal effects from those models indicate probability increases of $2.4 \%$ and $3.5 \%$, respectively, per 1,000 additional acres. Off-farm income is not statistically significant at the $10 \%$ level in any of the five models, suggesting that added income security provided through off-farm employment does not affect expressed interest in risk management training.

Percent borrowed is uniformly significant and its marginal effects are substantial. For example, operating with $50 \%$ debt versus no debt increases estimated probabilities of strong interest in additional training by $6.5 \%$ for forward contracting, $9.0 \%$ for futures and options, $6.0 \%$ for crop yield insurance, $6.4 \%$ for crop revenue insurance, and $11.0 \%$ for financial management. A lender's recommendation for use of a practice (recommended by lender) also has a uniformly positive and significant effect on interest in additional risk management education relating to the practice. Probability increases associated with lender recommendation are $9.5 \%$ for forward contracting, $13.5 \%$ for futures and options, $13.1 \%$ for crop yield insurance, and $13.4 \%$ for crop revenue insurance.

Producers who perceive themselves as being subject to high price risk have significantly larger probabilities of interest in educational programs in all five areas, whereas a perception of high yield risk has a significant positive effect for the insurance products only. Producers who reveal risk avoidance attitudes have significantly larger probability of expressing interest in education on all risk management practices except forward contracting, with probability increases from $5.5 \%$ for financial management to $11.9 \%$ for crop yield insurance. Degree of specific crop specialization has significant effects on interest in education relating to crop yield insurance and crop revenue insurance, but not the other risk management practices. Marginal effects of total specialization in cotton production are large, at $20.8 \%$ for yield insurance and $27.0 \%$ for revenue insurance. Similarly, marginal effects of specialization in wheat are $23.6 \%$ for crop yield insurance and $25.7 \%$ for crop revenue insurance. The only other crop that has a significant effect on expressed interest in any of the risk management areas is soybeans, with soybean specialization increasing the probability of strong interest in education on crop reventue insurance by $23.3 \% .^{8}$

\section{Summary and Concluding Comments}

Studies have suggested that prior to the mid1990 s, many agricultural economists had not found farmers receptive to risk management education. However, our survey results reveal that in the post-FAIR Act business climate a substantial number of farm operators have participated in risk management educational programs and express interest in additional risk

"Marginal effects of these variables can be regarded as changes in probabilities of strong desire for additional risk management education (in percentage terms) associated with complete specialization in the crop versus all other crops for which no proportion variables are included. The five crops in the model dominated the cropping systems of the producers surveyed, with only $6.2 \%$ of cropland devoted to all other crops. 
management training. Specifically, our fourstate results indicate that $55 \%$ of crop producers with gross farm revenue in excess of $\$ 25,000$ participated in risk management educational programs in at least one of three subject matter areas-marketing, insurance, and financial management-during the period from 1996 to 1998. Further, the survey responses show that $71 \%$ of these farmers express continued strong interest in risk management training in at least one of five areasforward contracting, futures and options, crop yield insurance, crop revenue insurance, and financial management.' .These results support the current policy emphasis on risk management education.

Our study findings also have implications regarding the content of risk management educational programs, how those programs should be delivered, and appropriate target audiences. Levels of interest in additional education in the five subject matter areas are $45 \%$ for forward contracting, $47 \%$ for futures and options, 32\% for crop yield insurance, 33\% for crop revenue insurance, and $45 \%$ for financial management. ${ }^{10}$ In-depth self-study and magazines and newsletters are popular methods of learning among farm operators of all ages. In-depth programs with risk management experts, Internet-based training and marketing clubs, and other producer organizations are somewhat less popular overall. However, the latter two learning methods have relatively strong appeal among younger farm operators.

The finding that only $35 \%$ of the producers indicate a willingness to take a lower price to reduce price risk suggests that many producers' perceptions of risk management strategies apparently do not reflect the risk/reward tradeoff that underlies most risk management concepts. If only $35 \%$ of producers are truly risk averse, then the audience for risk management

${ }^{3}$ The percentages reported here are weighted by population counts in each farm size stratum so that they are reflective of the population, rather than survey respondents.

10 The percentages reported here are weighted by population counts in each farm size stratum so that they are reflective of the population, rather than survey respondents. training is significantly constrained. One might question whether producers perceive a risk/reward tradeoff. If government programs provide significant price risk protection or producers have been taught that price risk management may allow both increased returns and lowered risk, then significant basic conceptual training may be needed to get producers started on sound risk management strategies.

Our probit model results show that younger farm operators are more likely to participate in educational programs on forward contracting, futures and options, and financial management. Thus some degree of tailoring and targeting of these programs to younger audiences appears appropriate. A similar approach for programs on crop yield and revenue insurance is not supported by our results. In general, future risk management education program participants will be relatively well educated, will have prior training in the use of the risk management practices, and will have used the practices in the past. This suggests that the content of at least some programs should be at an advanced level, perhaps with a progressive structure used to serve the needs of all producers. The lack of statistical significance for proportion of various crops in the models of forward contracting, futures and options, and financial management suggests that there are not significant crop-related disparities in the demand for risk management education. This result implies certain economies in the provision of risk management education. Programs developed for producers of one commodity might serve equally as well or be readily adapted to the needs of producers of other commodities, and general producer programs for these topics should be successful. However, our results support targeting of educational programs on crop yield and revenue insurance toward cotton and wheat producers, and perhaps similar targeting of revenue insurance programs toward soybeans producers.

Our results also indicate that producers with weaker equity positions and those whose lenders recommend use of risk management practices are more likely to participate in educational programs. They also suggest that lenders who favor use of risk management 
practices should clearly communicate what they advocate to their borrowers. This supports continued efforts by the RMA and CSREES to form partnerships with lending institutions and others in risk management educational efforts. However, extension educators appear to be uniquely qualified to integrate the various risk management training areas. Private sector marketing advisory services, lenders, crop insurance agents, and others have a strong incentive to provide risk management training associated with the particular service they offer. However, they commonly have incentives to sell a risk management product or service to the producer. It seems that extension educators can be the unbiased source of risk management information that integrates various forms of risk management, such as marketing, insurance, and financial management. For example, with the advent of revenue insurance, producers are protected from yield and/or price risk. Products such as these, which have a price risk component, potentially have a much different relationship with forward pricing than does yield insurance. This suggests that extension educators should be at the forefront in trying to integrate the analysis and understanding of various risk management tools.

As stated in the introduction, this study represents an unusual opportunity to provide in-depth analysis of educational needs, desired program emphasis, and target audience composition at an early stage of a major educational initiative. Some of our findings might be viewed as confirming prior expectations, whereas others might not have been anticipated. Both types of results should be useful to RMA and CSREES personnel charged with implementation of the initiative, to public and private sector educators who wish to contribute to the educational effort, and ultimately to policy makers who will judge the effectiveness with which the educational effort is carried out and make decisions regarding future needs.

\section{References}

Anclerson, K.B., and H.P. Mapp. "Risk Management Programs in Extension." Journal of Agricultural and Resource Economics 21(July 1996):31-38.

Asplund, N.M., D.L. Forster, and T. Stout. "Farmers' Use of Forward Contracting and Hedging." Review of Futures Markets 8(1989):24-37.

Ben-Porath, Y. "The Production of Human Capital and the Life Cycle of Earnings." Journal of Political Economy Part I, 75(August 1967):35265.

Collins, K.J., and J.W. Glauber. "Will Policy Changes Usher In a New Era of Increased Agricultural Market Variability?" Choices (Second Quarter 1998):26-29.

Goodwin, B.K., and T.C. Schroeder. "Human Capital, Producer Education Programs, and the Adoption of Forward Pricing Methods." American Journal of Agricultural Economics 76(November 1994):936-47.

Grimes, G.L. Personal communication from the University of Missouri, Columbia, August 2000.

Heady, E.O. "Extension Education in Improving Decisions of Indivictual Farmers." Paper presented at the proceedings of the Research Conference on Risk and Uncertainty in Agriculture, Bozeman, MT, August 1953, pp. 54-56.

Holt, J., and K.B. Anderson. "Teaching Decision Making Under Risk and Uncertainty to Farmers." American Joumal of Agricultural Economics 60(May 1978):249-53.

Johnson, G.L. "Relevant Theories, Concepts and Research Techniques." Paper presented at the proceedings of Research Conference on Risk and Uncertainty in Agriculture held in Bozeman, MT, August 1953, pp. 36-46.

Knight, F.H. Risk Uncertainty and Profit. New York: Kelly and Millman, 1937.

Likert, R. "A Technique for the Measurement of Attitudes." Archives of Psychology 140(June 1932):5-55.

Nelson, A.G., and T.D. Harris. "Designing an Instructional Package: The Use of Probabilities in Farm Decision Making." American Joumal of Agricultural Econonics 60(December 1978): 993-97.

Selley, R.A., and P.N. Wilson. "Risk Research and Public Outreach: A Tale of Two Cultures?" Joumal of Agricultural and Resource Econonics 22(December 1997):222-32.

Shapiro, B.I., and B.W. Brorsen. "Factors Influenc- 
ing Farmers' Decisions of Whether or Not to Hedge." North Central Journal of Agricultural Economics 10(1988):145-53.

Walker, O., and A.G. Nelson. "Dealing with Risks in the Management of Agricultural Farms: An
Extension/Teaching Viewpoint." Risk Analysis in Agriculture: Research and Educational Developinents, pp. 22-53. Champaign/Urbana: University of Illinois, Department of Agricultural Economics, AE-4492, June 1980. 